\title{
First report of Neofusicoccum batangarum causing grapevine dieback in Brazil
}

\author{
Tamiris J. S. Rêgo ${ }^{1} \cdot$ Fábio J. A. Silva ${ }^{1} \cdot K^{\prime}$ ledson M. Santos ${ }^{1} \cdot$ Marcos P. S. Câmara ${ }^{1} \cdot K_{\text {Kamila C. Correia }}{ }^{2}$ \\ Sami J. Michereff ${ }^{1,2}$
}

Received: 13 February 2019 / Accepted: 2 March 2020 / Published online: 10 March 2020

(C) Società Italiana di Patologia Vegetale (S.I.Pa.V.) 2020

Keywords Botryosphaeriaceae $\cdot$ Vitis labrusca $\cdot$ Fungal phylogeny

In 2015, grapevine (Vitis labrusca) branches with symptoms of dieback were collected in vineyards of the Siriji Valley, Pernambuco state, Brazil. Colonies morphologically similar to species of Botryosphaeriaceae were isolated from necrotic tissues. Four isolates (CMM 876, CMM 896, CMM 930, and CMM 943) presented colonies forming concentric rings, and white mycelium becoming gray to gray-olivaceous after 5 days in malt extract agar. The isolates showed conidiogenous cells holoblastic, and conidia hyaline, smooth, aseptate, fusoid to ovoid, thin-walled, and measured $15.8 \pm 1.5 \times 5.6 \pm 0.8 \mu \mathrm{m}$ $(n=50), \mathrm{L} / \mathrm{W}$ ratio $=2.7$, which are characteristics of Neofusicoccum spp. (Phillips et al. 2013). DNA sequencing of the EF1- $\alpha$, TUB and ITS genes were conducted as described by Marques et al. (2013). A phylogenetic analysis using Maximum Likelihood was carried out, showing that the isolated fungi belong to the $N$. batangarum clade. Sequences of the isolates were deposited in GenBank (EF1- $\alpha$, MG956819 to MG956822; TUB, MG979553 to MG979556; ITS, MG979494 to MG979497). Cultures were deposited in the Culture Collection of Phytopathogenic Fungi of the Universidade Federal Rural de Pernambuco, Recife, Brazil. Pathogenicity tests were performed with the strains of $N$. batangarum on grapevine seedlings (cv. Isabel) using mycelial plugs from colonies (PDA) of each isolate. After 21 days, inoculated seedlings showed dark vascular tissue

Electronic supplementary material The online version of this article (https://doi.org/10.1007/s42161-020-00538-x) contains supplementary material, which is available to authorized users.

Sami J. Michereff

sami.michereff@ufca.edu.br

1 Programa de Pós-Graduação em Fitopatologia, Universidade Federal Rural de Pernambuco, Recife, Pernambuco 52171-900, Brazil

2 Centro de Ciências Agrárias e da Biodiversidade, Universidade Federal do Cariri, Crato, Ceará 63133-610, Brazil with a size lesion $6.3 \mathrm{~cm} \pm 1.4 \mathrm{~cm}$. No symptoms were observed in the control seedlings. The pathogen was reisolated from inoculated seedlings and identified by conidia morphology to fulfill Koch's postulates. Neofusicoccum batangarum was identified associated with Anacardium othonianum and Nopalea cochenillifera in Brazil, Ficus insipida in Panama, Opuntia ficus-indica in Italy, Schinus terebinthifolius in the United States, and Terminalia catappa in Cameroon (Farr and Rossman 2019). To our knowledge, this is the first report of $N$. batangarum causing grapevine dieback in Brazil and worldwide.

\section{References}

Farr DF, Rossman AY (2019). Fungal databases. U.S. National Fungus Collections, ARS, USDA. https://nt.ars-grin.gov/fungaldatabases. Accessed 12 February 2019

Marques MW, Lima NB, Morais MA Jr, Michereff SJ, Phillips AJL, Câmara MPS (2013) Botryosphaeria, Neofusicoccum, Neoscytalidium and Pseudofusicoccum species associated with mango in Brazil. Fungal Divers 61(1):195-208

Phillips A, Alves A, Abdollahzadeh J, Slippers B, Wingfield M, Groenewald J, Crous P (2013) The Botryosphaeriaceae: genera and species known from culture. Stud Mycol 76(1):51-167

Publisher's note Springer Nature remains neutral with regard to jurisdictional claims in published maps and institutional affiliations. 